\title{
Mini review: immunologic functions of dual oxidases in mucosal systems of vertebrates
}

\author{
H. T. Yang ${ }^{a *}$ (D), Y. H. Huang ${ }^{a}$ (D) and G. W. Yang ${ }^{a}$ \\ aShandong Provincial Key Laboratory of Animal Resistance Biology, College of Life Sciences, Shandong Normal \\ University, 250014, Jinan, Shandong, China \\ *e-mail: yanghuiting@sdnu.edu.cn
}

Received: September 15, 2018 - Accepted: May 8, 2019 - Distributed: November 30, 2020

(With 1 figure)

\begin{abstract}
Mucosal epithelial cells act as the first immunologic barrier of organisms, and contact directly with pathogens. Therefore, hosts must have differential strategies to combat pathogens efficiently. Reactive oxygen species (ROS), as a kind of oxidizing agents, participates in the early stage of killing pathogens quickly. Recent reports have revealed that dual oxidase (DUOX) plays a key role in mucosal immunity. And the DUOX is a transmembrane protein which produces ROS as their primary enzymatic products. This process is an important pattern for eliminating pathogens. In this review, we highlight the DUOX immunologic functions in the respiratory and digestive tract of vertebrates.
\end{abstract}

Keywords: NADPH oxidases, dual oxidase, innate immunity, mucosal immunity.

\section{Minirrevisão: funções imunológicas de oxidases duplas em sistemas mucosos de vertebrados}

\section{Resumo}

As células epiteliais da mucosa atuam como a primeira barreira imunológica dos organismos e entram em contato direto com os patógenos. Portanto, os hospedeiros devem ter estratégias diferenciadas para combater os patógenos de forma eficiente. Trabalhos recentes revelaram que a oxidase dupla (DUOX) desempenha um papel fundamental para a imunidade da mucosa. A DUOX é uma proteína transmembrana geradora de espécies reativas de oxigênio (EROs) como seus principais produtos enzimáticos. Nesta revisão, apresentaremos as funções imunológicas da DUOX no trato respiratório e digestivo dos vertebrados.

Palavras-chave: NADPH oxidases, oxidase dupla, imunidade inata, imunidade da mucosa.

\section{Dual Oxidase is a Member of NADPH Oxidases}

DUOXs belong to the family of nicotinamide adenine dinucleotide phosphate (NADPH) oxidases and are the primary sources of $\mathrm{H}_{2} \mathrm{O}_{2}$ production in a wide range of organisms. NADPH oxidases (NOXs) represent a family of enzymes, which directly regulate cellular production of reactive oxygen species (ROS) and play various functional roles in physiology (Laurindo et al., 2014). ROS includes $\mathrm{H}_{2} \mathrm{O}_{2}$, hydroxyl radical $(\cdot \mathrm{OH})$, superoxide anion $\left(\mathrm{O}_{2} \cdot{ }^{--}\right)$and singlet oxygen $\left({ }^{1} \mathrm{O}_{2}\right)$ species (Cao et al., 2017; Li et al., 2012; Pang et al., 2011). There are 7 members, including 5 NOX enzymes (NOX1-5) and 2 DUOX enzymes (DUOX1 and DUOX2), in the human genome. DUOXs were originally identified as NADPH oxidases producing $\mathrm{H}_{2} \mathrm{O}_{2}$ necessary for thyroid hormone biosynthesis for the iodination process in the thyroid gland (De Deken et al., 2000; Dupuy et al., 1999). NOXs have a conserved catalytic core, which is responsible for transmembrane electron transfer. The intracellular electron donors are transferred to the extracellular compartment, and subsequently, generate superoxide or $\mathrm{H}_{2} \mathrm{O}_{2}$ (De Deken et al., 2014). Under normal conditions, most NOX isoforms have very low or no constitutive activity but their expression can be increased after pathogens' invasion. Under these conditions, the activated NOXs can generate high ROS levels leading to increased oxidative stress (Sarr et al., 2018). Oxidative stress commonly is used as a defense mechanism for killing foreign microorganisms (Xiong et al., 2018). The role of ROS as microbicidal effectors is obvious during the oxidative burst of phagocytes (Babior, 2004). In the absence of the NOX2 gene, humans are prone to severe microbial infection. Therefore, ROS generated by NOXs is important in immunity.

The molecular structure of the NOX family members share high homology between them. NOX2 contains two heme groups in the N-terminal region, which is composed of six transmembrane $\alpha$-helical domains, and one NAD 
binding domain and one flavin adenine dinucleotide binding domains in the $\mathrm{C}$-terminal region. The basic structure of NOX1, NOX3 and NOX4 is similar to that of NOX2. NOX5 has a short $\mathrm{N}$-terminal extension of $\mathrm{Ca}^{2+}$-responsive $\mathrm{EF}$ hand motifs (Ameziane-El-Hassani et al., 2005; Bae et al., 2010; Grandvaux et al., 2015) (Figure 1).

In phagocytes, the catalytic protein NOX2 serves as a core protein in the oxidase complex (Segal, 2005). Excessive ROS production is also very detrimental to the host, therefore there are many signaling pathways which can inhibit the NOXs' activity (Lambeth et al., 2007; Leto et al., 2009). To gain full activation, it is necessary that five molecules must combine with NOX2, including one membrane-integrated protein (p22phox), three cytosolic proteins (p47phox, p40phox and p67phox), and one small G-protein Rac. After pathogen challenge, NOX2 tightly associates with p22phox to form cytochrome b558, which leads to the recruitment of cytosolic proteins and Rac (Bae et al., 2010). NOX2 produces superoxide from molecular oxygen (Babior et al., 1973; Leto and Geiszt, 2006). Superoxide then dismutates into $\mathrm{H}_{2} \mathrm{O}_{2}$ enzymatically or non-enzymatically. $\mathrm{H}_{2} \mathrm{O}_{2}$ can then be converted to the highly microbicidal $\mathrm{HOCl}$ by an enzyme known as myeloperoxidase (Klebanoff, 2005).
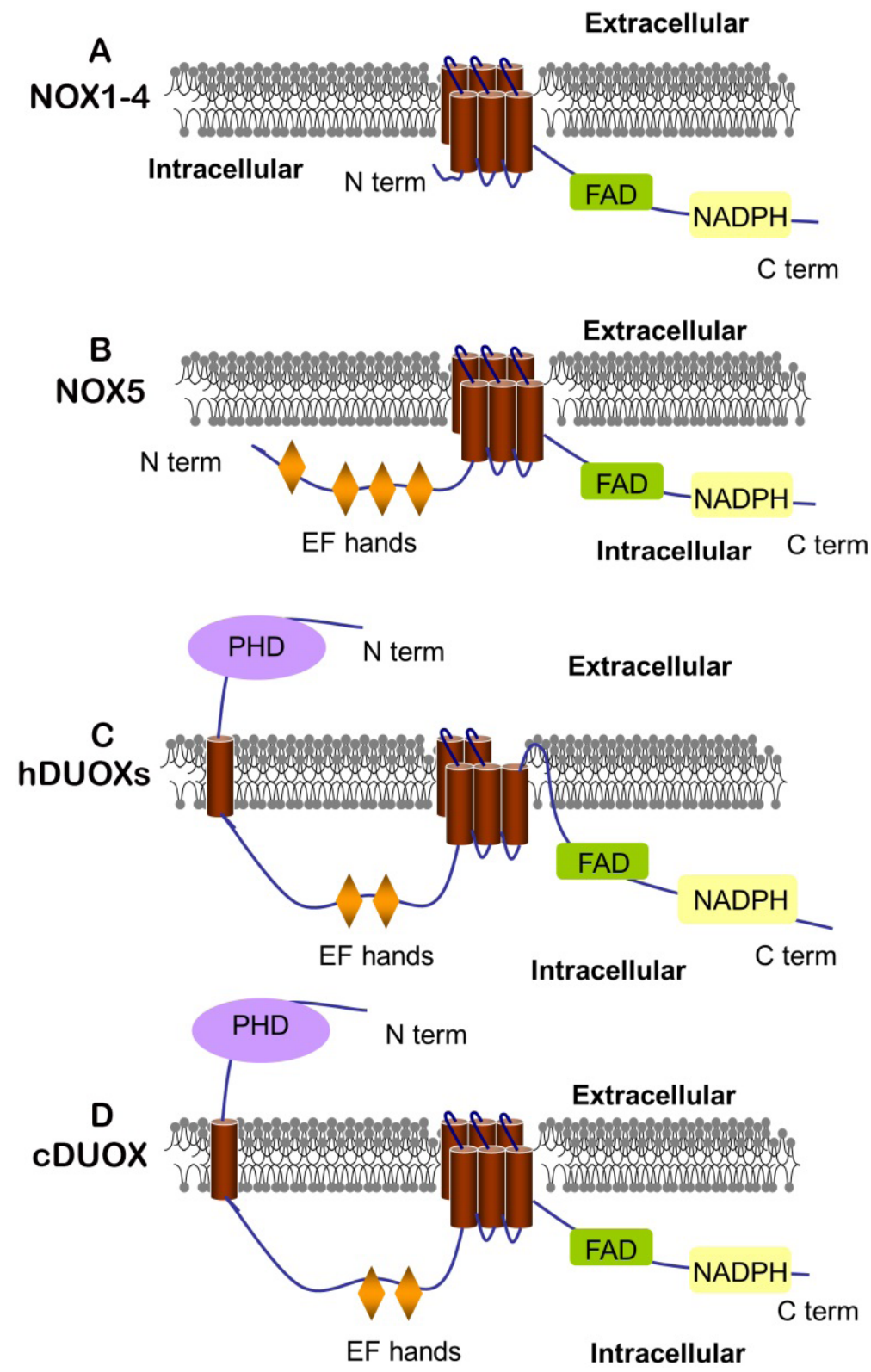

Figure 1. NOXs and DUOXs structure of the NADPH oxidase family. (A) The struction of NOX1-4; (B) The structure of NOX5; (C) The struction of DUOXs from humans; (D) The struction of DUOX from Caenorhabditis elegans. PHD = peroxidase homology domain; $\mathrm{EF}$ hands = calcium-binding region; FAD = FAD-binding domain; NADPH = NADPH-binding domain. 


\section{DUOX's Characterization}

DUOXs share conserved motifs, including one peroxidase homology domain in the N-terminal region, which is a crucial extracellular matrix with tyrosine-crosslinking activity, two $\mathrm{Ca}^{2+}$ binding domain (EF hand), five or six transmembrane domains, one FAD binding domain and one NAD binding domain (Figure 1) (Bae et al., 2010; Rigutto et al., 2009; Yang et al., 2016). Once thought to be an exclusive feature of phagocytes, ROS production by DUOXs has now also been described in several different tissues and cells in many animals (Bedard and Krause, 2007).

DUOX-mediated generation of ROS needs to be regulated by enzymatic activity and gene expression. Previous reports indicate that uracil acts as a ligand that induces the activity of the Hedgehog (Hh) signaling pathway. In this pathway, a kind of calcium-dependent cell adhesion molecule, Cadherin 99C, expression levels increase can induce $\mathrm{Ca}^{2+}$ mobilization together with phospholipase $\mathrm{C} \beta$ and protein kinase $\mathrm{C}$. The high $\mathrm{Ca}^{2+}$ concentration in the cytoplasm initiates DUOX enzymatic activity (Lee et al., 2015a). Additionally, the induction of lipid raft formation, lipolysis, and CaMKII can promote DUOX enzymatic activity (Lee et al., 2018, 2015b). DUOX-mediated ROS production requires the formation of a DUOX complex rather than an individual DUOX molecule. DUOX activator 2 (DUOXA2) can associate with DUOX2 and form a stable complex. The complex is crucial for $\mathrm{H}_{2} \mathrm{O}_{2}$ generation by DUOX2. The disulfide bridge formed between DUOX2 and DUOXA 2 has been reported to be very important for the function of the complex (Casas et al., 2015).

$D U O X$ gene expression is highly upregulated in response to pathogen infections (Geiszt et al., 2003; Ha et al., 2005). Some studies have shown that the NF- $\mathrm{BB}$ pathway triggered by bacteria can elicit and promote $D U O X$ expression (Ha et al., 2009). Pseudomonas aeruginosa flagellin can induce $D U O X$ expression and ROS production in human bronchial epithelial cells (Gattas et al., 2009). DUOX1 mRNA levels are moderately upregulated by Th2 cytokines such as IL-4 and IL-13. DUOX1 expression is promoted by IL-4 in the thyroid of transgenic mice (Eskalli et al., 2016). However, DUOX2 mRNA levels are enhanced by cytokine interferon- $\gamma$ in primary respiratory tract epithelial cells (Harper et al., 2005). DUOX2 expression has also been reported to be elevated by polycytidylic acid (poly (I:C)) and rhinovirus infection in primary airway epithelial cells. These findings indicate that the two types of DUOXs have distinct functions under different physiological processes. Mucosal immune dysbiosis could increase the expression of DUOX2 in the mice intestine (Grasberger et al., 2015). Mitogen activated protein $\mathrm{p} 38 \mathrm{c}$ is expressed in the midgut and can induce the expression of DUOX (Chakrabarti et al., 2014). However, the accurate intracellular signaling mechanism by which $D U O X$ expression is regulated has not yet been elucidated.

\section{DUOX's Immunologic Functions}

$D U O X 1$ and $D U O X 2$ were first cloned from porcine and human thyroid glands. In $D U O X 2$ mutated mice, congenital hypothyroidism was observed. This demonstrated that DUOX2 has thyroid hormone biosynthesis function (Louzada et al., 2018; Moreno et al., 2002; Weber et al., 2013). However, DUOX expression is not confined to the thyroid gland; the enzyme is present in various epithelial cell types on the mucosal surfaces of the respiratory and gastrointestinal tract (Geiszt et al., 2003; Hampton et al., 1998; Rada and Leto, 2008). This suggests that DUOXs have important roles in innate immunity pathways. DUOXs produce $\mathrm{H}_{2} \mathrm{O}_{2}$, which is an effective antimicrobial compound against a broad range of bacteria (Gerson et al., 2000; Oram and Reiter, 1966).

\subsection{DUOXs' immunologic functions in the respiratory tract}

Both DUOX1 and DUOX2 are expressed in the respiratory epithelium. Earlier on, DUOX1 was considered as the main isoform responsible for extracellular $\mathrm{H}_{2} \mathrm{O}_{2}$ production in response to bacterial stimulation (Boots et al., 2009; Forteza et al., 2005; Koff et al., 2008). In contrast, the function of DUOX2 was mainly considered to be involved in differentiated airway epithelial cells (Gattas et al., 2009; Linderholm et al., 2010). However, in recent years, reports have suggested that DUOX2 produces extracellular $\mathrm{H}_{2} \mathrm{O}_{2}$ which also has antimicrobial function in mammalian airway epithelial cells (Moskwa et al., 2007). The bacterial component flagellin induces the airway mucosa to promote the DUOX2-mediated ROS release and trigger innate immune responses via TLR5 activiation (Joo et al., 2012). Pseudomonas aeruginosa obtained from long-term cultures inhibits DUOX1-dependent hydrogen peroxide release, and purified pyocyanin from $P$. aeruginosa can inhibit the dual oxidase-based antimicrobial system of airway epithelial cells (Rada et al., 2008).

Virus infection of the respiratory tract usually results in severe respiratory diseases (He et al., 2016; Hou et al., 2017, 2018; Liang et al., 2010; Zheng et al., 2018). DUOX2 and its maturation factor DUOXA2 in the respiratory mucosa could be upregulated by viral infection and some cytokines (Interleukin I ( $\alpha$ and $\beta$ ) and II ( $\gamma$ ) IFNs and Th1) (Fink et al., 2013; Strengert et al., 2014). Influenza A virus (IAV) infection can lead to coordinated up-regulation of DUOX2, which generates $\mathrm{H}_{2} \mathrm{O}_{2}$. After $\mathrm{H}_{2} \mathrm{O}_{2}$ decomposition, the IAV replication levels are augmented. Furthermore, when the expression of DUOX was blocked, 2009 pandemic H1N1 influenza virus was more likely to load on intranasal infection (Strengert et al., 2014). Respiratory syncytial virus (RSV) is the most frequent cause of bronchiolitis in infants and children worldwide. In a perinatal lamb model, after RSV infection, DUOX expression levels were increased under bronchiolitis (Derscheid and Ackermann, 2012). Retinoic acid inducible gene 1 and melanoma differentiation-associated protein 5 also can induce DUOX2-mediated antiviral responses (Kim et al., 2015). In chronic rhinosinusitis (CRS), DUOX mRNA levels were significantly elevated. The expression levels of eotaxin and TNF- $\alpha$ closely correlated with the expression of DUOX. These results indicate that DUOX is implicated in the inflammatory response in CRS (Cho et al., 2013). 
In some cases, viral infection can also induce the expression of DUOX1 (Grandvaux et al., 2015). However, DUOX1 is a commonly critical protein in the pathogenesis of allergic airways according to its association with type 2 immune responses and the its ability to interact with type 2 cytokines (Comhair and Erzurum, 2010; Sugiura and Ichinose, 2008; Suzuki et al., 2016; Van der Vliet et al., 2018). IL-4 and IL-13, can recruit neutrophils in airways to promote allergic asthma (Chang et al., 2013). It has been reported that DUOX1 mRNA and protein levels increased and promoted IL-33 secretion in cultured nasal or bronchial epithelial cells from humans or model animals with allergic asthma (Habibovic et al., 2016; Hristova et al., 2016; Wan et al., 2016).

\subsection{DUOX immune function in the digestive tract}

Vertebrate guts harbor large amounts of microorganisms. In the human gut, there are approximately $10^{14}$ microbial cells from over 500 species which reside in the barrier epithelia (Goodacre, 2007; Savage, 1977; Tannock, 2005). It has been confirmed that DUOX2 is expressed all along the digestive tract, where it provides a novel source of $\mathrm{H}_{2} \mathrm{O}_{2}$, particularly in the cecum, ileum and colon (El Hassani et al., 2005; Sommer and Backhed, 2015).

Segmented filamentous bacteria up-regulate the expression of DUOX2 in the mice intestinal tract. Mucosal cytokine IL-22 increases the expression of DUOX2. However, IL-17 or IL-22 are not required for DUOX2 transcription (Grasberger et al., 2015). In the inflamed human colon, DUOX protein expression is highly elevated in the apical, lateral and perinuclear membrane along the whole length of the gland. DUOX2 induces exfoliation of the crypt epithelium, which is a major contributor to inflammation. Therefore, DUOX2 may be a potential therapeutic target for treating ileocolitis inflammatory bowel disease (Chu et al., 2017). Helicobacter pylori infection causes the most common human chronic infection. In wild-type mice, infection with Helicobacter felis induces the expression of DUOX2 and DUOXA2 in the stomach (Grasberger et al., 2013). In a colon study, it was demonstrated that a sentinel goblet cell guards the colonic crypt by triggering Nlrp6-dependent Muc2 secretion. This goblet cell nonspecifically endocytoses and reacts to the TLR2/1, TLR4, and TLR5 ligands, and then induces the DUOX-dependent ROS synthesis against persisting pathogens (Birchenough et al., 2016). In intestinal immunity of aquatic animals, the function of DUOX has been studied. Based on the advantages of the zebrafish genetic background, it has been used as good animal model to study intestinal immunity. Zebrafish DUOX is highly expressed in intestinal epithelial cells. After knockdown of DUOX, zebrafish larvae had impaired capacity to control enteric Salmonella infection (Flores et al., 2010). It has been reported that DUOX is activated following ligand-dependent stimulation of TLRs via interacting microbial components. However, the mechanism by which TLR stimulation leads to DUOX activation is less clear. Previous experiments have shown that DUOX is physically associated with at least some members of the TLR family, such as the TLR2 and the TLR5 (Joo et al., 2012). In the common carp (Cyprinus carpio L.), many mucosal immunity associated molecules, such as the Rig-I-like receptors, TLRs, pIgR-like molecule, interferon regulatory factors, interleukin-1 receptor-associated kinase 1, and antimicrobial peptides, have shown immunity functions (Chen et al., 2018; Li et al., 2013, 2017; Rombout et al., 2014; Shan et al., 2015; Yang et al., 2014, 2017; Zhang et al., 2015; Zhu et al., 2016a, b). Various TLRs have been identified in Cyprinus carpio L., including the TLR4, 18, 21, 22. In addition, these TLRs can participate in various antimicrobial and antiviral responses (Li et al., 2018; Shan et al., 2018; Westfall et al., 2017). However, there are no reports that clearly show the relationship between TLRs and DUOX activation in fish.

Enterovirus infection usually results in host's diarrhea, and weak or severe fever. The microbiota diversity was increased in the intestine after humanized pigs were infected with human rotavirus (Kumar et al., 2018). Transmissible gastroenteritis virus (TGEV) causes pig diarrhea. After TGEV infection, the mRNA levels of cytokines, including IL-1 $\beta$, IL-6, IL-8 TNF- $\alpha$ and IL-10, were significantly enhanced. Additionally, the number of Lactobacillus decreased, while the number of Enterobacteriaceae increased (Xia et al., 2018; Zhang et al., 2018). Newcastle disease virus can induce oxidative stress and tissue damage in the intestine of chickens. Vitamin E supplementation alleviates this condition (Rehman et al., 2018). However, few studies have reported the relationship of DUOXs with viral infection in the intestine.

\section{Conclusion}

In this review, we summarized the current knowledge with respect to the importance of DUOX enzymes in mucosal epithelia, especially in the respiratory tract and the digestive tract. In the respiratory tract, DUOX1 mainly participates in antimicrobial responses, and also in allergic airways. However, DUOX2 plays an important role against viral infection in the respiratory mucosa. The mucosal immunity in the intestine is necessary for the host's health, considering the complexity of the local environment. DUOXs can indeed participate in antibacterial processes. However, the signaling pathways regulating the DUOXs have not been revealed. It is merely reported that enterovirus infection induces oxidase stress. Whether viral infection induces DUOXs expression and activation has not been uncovered. Additionally, it is necessary to study the expression and activation of the molecular mechanism of function of DUOXs in mucosal immunity.

\section{Acknowledgements}

This work was supported by grant from Shandong University Scientific Research Project (No. J18KB081). 


\section{References}

AMEZIANE-EL-HASSANI, R., MORAND, S., BOUCHER, J.L., FRAPART, Y.M., APOSTOLOU, D., AGNANDJI, D., GNIDEHOU, S., OHAYON, R., NOEL-HUDSON, M.S., FRANCON, J., LALAOUI, K., VIRION, A. and DUPUY, C., 2005. Dual oxidase-2 has an intrinsic $\mathrm{Ca}^{2+}$-dependent $\mathrm{H}_{2} \mathrm{O}_{2}$ generating activity. The Journal of Biological Chemistry, vol. 280, no. 34, pp. 30046-30054. http://dx.doi.org/10.1074/jbc. M500516200. PMid:15972824.

BABIOR, B.M., 2004. NADPH oxidase. Current Opinion in Immunology, vol. 16, no. 1, pp. 42-47. http://dx.doi.org/10.1016/j. coi.2003.12.001. PMid:14734109.

BABIOR, B.M., KIPNES, R.S. and CURNUTTE, J.T., 1973. Biological defense mechanisms: the production by leukocytes of superoxide, a potential bactericidal agent. The Journal of Clinical Investigation, vol. 52, no. 3, pp. 741-744. http://dx.doi. org/10.1172/JCI107236. PMid:4346473.

BAE, Y.S., CHOI, M.K. and LEE, W.J., 2010. Dual oxidase in mucosal immunity and host-microbe homeostasis. Trends in Immunology, vol. 31, no. 7, pp. 278-287. http://dx.doi.org/10.1016/j. it.2010.05.003. PMid:20579935.

BEDARD, K. and KRAUSE, K.H., 2007. The NOX family of ROS-generating NADPH oxidases: physiology and pathophysiology. Physiological Reviews, vol. 87, no. 1, pp. 245-313. http://dx.doi. org/10.1152/physrev.00044.2005. PMid:17237347.

BIRCHENOUGH, G.M., NYSTROM, E.E., JOHANSSON, M.E. and HANSSON, G.C., 2016. A sentinel goblet cell guards the colonic crypt by triggering Nlrp6-dependent Muc2 secretion. Science, vol. 352, no. 6293, pp. 1535-1542. http://dx.doi.org/10.1126/ science.aaf7419. PMid:27339979.

BOOTS, A.W., HRISTOVA, M., KASAHARA, D.I., HAENEN, G.R., BAST, A. and VAN DER VLIET, A., 2009. ATP-mediated activation of the NADPH oxidase DUOX1 mediates airway epithelial responses to bacterial stimuli. The Journal of Biological Chemistry, vol. 284, no. 26, pp. 17858-17867. http://dx.doi. org/10.1074/jbc.M809761200. PMid:19386603.

CAO, S., DU, X.H., LI, L.H., LIU, Y.D., ZHANG, L., PAN, X., LI, Y., LI, H. and LU, H., 2017. Overexpression of Populus tomentosa cytosolic ascorbate peroxidase enhances abiotic stress tolerance in tobacco plants. Russian Journal of Plant Physiology: a Comprehensive Russian Journal on Modern Phytophysiology, vol. 64, no. 2, pp. 224-234. http://dx.doi.org/10.1134/S1021443717020029.

CASAS, A.I., DAO, V.T., DAIBER, A., MAGHZAL, G.J., DI LISA, F., KALUDERCIC, N., LEACH, S., CUADRADO, A., JAQUET, V., SEREDENINA, T., KRAUSE, K.H., LOPEZ, M.G., STOCKER, R., GHEZZI, P. and SCHMIDT, H.H., 2015. Reactive oxygen-related diseases: therapeutic targets and emerging clinical indications. Antioxidants \& Redox Signalling, vol. 23, no. 14, pp. 1171-1185. http://dx.doi.org/10.1089/ars.2015.6433. PMid:26583264.

CHAKRABARTI, S., POIDEVIN, M. and LEMAITRE, B., 2014. The Drosophila MAPK p38c regulates oxidative stress and lipid homeostasis in the intestine. PLOS Genetics, vol. 10, no. 9, pp. e1004659. http://dx.doi.org/10.1371/journal.pgen.1004659. PMid:25254641.

CHANG, S., LINDERHOLM, A., FRANZI, L., KENYON, N., GRASBERGER, H. and HARPER, R., 2013. Dual oxidase regulates neutrophil recruitment in allergic airways. Free Radical
Biology \& Medicine, vol. 65, pp. 38-46. http://dx.doi.org/10.1016/j. freeradbiomed.2013.06.012. PMid:23770197.

CHEN, L., YAN, J., SHI, J., SUN, W., CHEN, Z., YU, J., QI, J., DU, Y., ZHANG, H. and FENG, L., 2018. Zebrafish intelectin 1 (zITLN1) plays a role in the innate immune response. Fish \& Shellfish Immunology, vol. 83, pp. 96-103. http://dx.doi. org/10.1016/j.fsi.2018.09.004. PMid:30195915.

CHO, D.Y., NAYAK, J.V., BRAVO, D.T., LE, W., NGUYEN, A., EDWARD, J.A., HWANG, P.H., ILLEK, B. and FISCHER, H., 2013. Expression of dual oxidases and secreted cytokines in chronic rhinosinusitis. International Forum of Allergy \& Rhinology, vol. 3, no. 5, pp. 376-383. http://dx.doi.org/10.1002/ alr.21133. PMid:23281318.

CHU, F.F., ESWORTHY, R.S., DOROSHOW, J.H., GRASBERGER, H., DONKO, A., LETO, T.L., GAO, Q. and SHEN, B., 2017. Deficiency in Duox2 activity alleviates ileitis in GPx1- and GPx2knockout mice without affecting apoptosis incidence in the crypt epithelium. Redox Biology, vol. 11, pp. 144-156. http://dx.doi. org/10.1016/j.redox.2016.11.001. PMid:27930931.

COMHAIR, S.A. and ERZURUM, S.C., 2010. Redox control of asthma: molecular mechanisms and therapeutic opportunities. Antioxidants \& Redox Signalling, vol. 12, no. 1, pp. 93-124. http:// dx.doi.org/10.1089/ars.2008.2425. PMid:19634987.

DE DEKEN, X., CORVILAIN, B., DUMONT, J.E. and MIOT, F., 2014. Roles of DUOX-mediated hydrogen peroxide in metabolism, host defense, and signaling. Antioxidants \& Redox Signalling, vol. 20, no. 17, pp. 2776-2793. http://dx.doi. org/10.1089/ars.2013.5602. PMid:24161126.

DE DEKEN, X., WANG, D., MANY, M.C., COSTAGLIOLA, S., LIBERT, F., VASSART, G., DUMONT, J.E. and MIOT, F., 2000. Cloning of two human thyroid cDNAs encoding new members of the NADPH oxidase family. The Journal of Biological Chemistry, vol. 275, no. 30, pp. 23227-23233. http://dx.doi. org/10.1074/jbc.M000916200. PMid:10806195.

DERSCHEID, R.J. and ACKERMANN, M.R., 2012. Perinatal lamb model of respiratory syncytial virus (RSV) infection. Viruses, vol. 4, no. 10, pp. 2359-2378. http://dx.doi.org/10.3390/ v4102359. PMid:23202468.

DUPUY, C., OHAYON, R., VALENT, A., NOEL-HUDSON, M.S., DEME, D. and VIRION, A., 1999. Purification of a novel flavoprotein involved in the thyroid NADPH oxidase: cloning of the porcine and human cdnas. The Journal of Biological Chemistry, vol. 274, no. 52, pp. 37265-37269. http://dx.doi.org/10.1074/ jbc.274.52.37265. PMid:10601291.

EL hASSANI, R.A., BENFARES, N., CAILlOU, B., TALBOT, M., SABOURIN, J.C., BELOTTE, V., MORAND, S., GNIDEHOU, S., AGNANDJI, D., OHAYON, R., KANIEWSKI, J., NOEL-HUDSON, M.S., BIDART, J.M., SCHLUMBERGER, M., VIRION, A. and DUPUY, C., 2005. Dual oxidase2 is expressed all along the digestive tract. American Journal of Physiology. Gastrointestinal and Liver Physiology, vol. 288, no. 5, pp. G933-G942. http://dx.doi.org/10.1152/ ajpgi.00198.2004. PMid:15591162.

ESKALli, Z., ACHOURI, Y., HAHN, S., MANY, M.C., CRAPS, J., REFETOFF, S., LIAO, X.H., DUMONT, J.E., VAN SANDE, J., CORVILAIN, B., MIOT, F. and DE DEKEN, X., 2016. Overexpression of interleukin-4 in the thyroid of transgenic mice upregulates the expression of Duox 1 and the anion transporter Pendrin. Thyroid, vol. 26, no. 10, pp. 1499-1512. http://dx.doi. org/10.1089/thy.2016.0106. PMid:27599561. 
FINK, K., MARTIN, L., MUKAWERA, E., CHARTIER, S., DE DEKEN, X., BROCHIERO, E., MIOT, F. and GRANDVAUX, N., 2013. IFNbeta/TNFalpha synergism induces a non-canonical STAT2/IRF9-dependent pathway triggering a novel DUOX2 NADPH oxidase-mediated airway antiviral response. Cell Research, vol. 23, no. 5, pp. 673-690. http://dx.doi.org/10.1038/ cr.2013.47. PMid:23545780.

FLORES, M.V., CRAWFORD, K.C., PULLIN, L.M., HALL, C.J., CROSIER, K.E. and CROSIER, P.S., 2010. Dual oxidase in the intestinal epithelium of zebrafish larvae has anti-bacterial properties. Biochemical and Biophysical Research Communications, vol. 400, no. 1, pp. 164-168. http://dx.doi.org/10.1016/j.bbrc.2010.08.037. PMid:20709024.

FORTEZA, R., SALATHE, M., MIOT, F., FORTEZA, R. and CONNER, G.E., 2005. Regulated hydrogen peroxide production by Duox in human airway epithelial cells. American Journal of Respiratory Cell and Molecular Biology, vol. 32, no. 5, pp. 462-469. http://dx.doi.org/10.1165/rcmb.2004-0302OC. PMid:15677770.

GATTAS, M.V., FORTEZA, R., FRAGOSO, M.A., FREGIEN, N., SALAS, P., SALATHE, M. and CONNER, G.E., 2009. Oxidative epithelial host defense is regulated by infectious and inflammatory stimuli. Free Radical Biology \& Medicine, vol. 47, no. 10, pp. 1450-1458. http://dx.doi.org/10.1016/j. freeradbiomed.2009.08.017. PMid:19703552.

GEISZT, M., WITTA, J., BAFFI, J., LEKSTROM, K. and LETO, T.L., 2003. Dual oxidases represent novel hydrogen peroxide sources supporting mucosal surface host defense. The FASEB Journal, vol. 17, no. 11, pp. 1502-1504. http://dx.doi. org/10.1096/fj.02-1104fje. PMid:12824283.

GERSON, C., SABATER, J., SCURI, M., TORBATI, A., COFFEY, R., ABRAHAM, J.W., LAUREDO, I., FORTEZA, R., WANNER, A., SALATHE, M., ABRAHAM, W.M. and CONNER, G.E., 2000. The lactoperoxidase system functions in bacterial clearance of airways. American Journal of Respiratory Cell and Molecular Biology, vol. 22, no. 6, pp. 665-671. http:// dx.doi.org/10.1165/ajrcmb.22.6.3980. PMid:10837362.

GOODACRE, R., 2007. Metabolomics of a superorganism. The Journal of Nutrition, vol. 137, no. 1, suppl., pp. 259S-266S. http:// dx.doi.org/10.1093/jn/137.1.259S. PMid:17182837.

GRANDVAUX, N., MARIANI, M. and FINK, K., 2015. Lung epithelial NOX/DUOX and respiratory virus infections. Clinical Science, vol. 128, no. 6, pp. 337-347. http://dx.doi.org/10.1042/ CS20140321. PMid:25456319.

GRASBERGER, H., EL-ZAATARI, M., DANG, D.T. and MERCHANT, J.L., 2013. Dual oxidases control release of hydrogen peroxide by the gastric epithelium to prevent Helicobacter felis infection and inflammation in mice. Gastroenterology, vol. 145, no. 5, pp. 1045-1054. http://dx.doi.org/10.1053/j.gastro.2013.07.011. PMid:23860501.

GRASBERGER, H., GAO, J., NAGAO-KITAMOTO, H., KITAMOTO, S., ZHANG, M., KAMADA, N., EATON, K.A., EL-ZAATARI, M., SHREINER, A.B., MERCHANT, J.L., OWYANG, C. and KAO, J.Y., 2015. Increased expression of DUOX2 is an epithelial response to mucosal dysbiosis required for immune homeostasis in mouse intestine. Gastroenterology, vol. 149 , no. 7, pp. 1849-1859. http://dx.doi.org/10.1053/j. gastro.2015.07.062. PMid:26261005.

HA, E.M., LEE, K.A., SEO, Y.Y., KIM, S.H., LIM, J.H., OH, B.H., KIM, J. and LEE, W.J., 2009. Coordination of multiple dual oxidase-regulatory pathways in responses to commensal and infectious microbes in Drosophila gut. Nature Immunology, vol. 10, no. 9, pp. 949-957. http://dx.doi.org/10.1038/ni.1765. PMid:19668222.

HA, E.M., OH, C.T., BAE, Y.S. and LEE, W.J., 2005. A direct role for dual oxidase in Drosophila gut immunity. Science, vol. 310, no. 5749, pp. 847-850. http://dx.doi.org/10.1126/science.1117311. PMid:16272120.

HABIBOVIC, A., HRISTOVA, M., HEPPNER, D.E., DANYAL, K., ATHER, J.L., JANSSEN-HEININGER, Y.M., IRVIN, C.G., POYNTER, M.E., LUNDBLAD, L.K., DIXON, A.E., GEISZT, M. and VAN DER VLIET, A., 2016. DUOX1 mediates persistent epithelial EGFR activation, mucous cell metaplasia, and airway remodeling during allergic asthma. JCI Insight, vol. 1, no. 18, pp. e88811. http://dx.doi.org/10.1172/jci.insight.88811. PMid:27812543.

HAMPTON, M.B., KETTLE, A.J. and WINTERBOURN, C.C., 1998. Inside the neutrophil phagosome: oxidants, myeloperoxidase, and bacterial killing. Blood, vol. 92, no. 9, pp. 3007-3017. http:// dx.doi.org/10.1182/blood.V92.9.3007. PMid:9787133.

HARPER, R.W., XU, C., EISERICH, J.P., CHEN, Y., KAO, C.Y., THAI, P., SETIADI, H. and WU, R., 2005. Differential regulation of dual NADPH oxidases/peroxidases, Duox1 and Duox 2, by Th1 and Th2 cytokines in respiratory tract epithelium. FEBS Letters, vol. 579, no. 21, pp. 4911-4917. http://dx.doi. org/10.1016/j.febslet.2005.08.002. PMid:16111680.

HE, C.Q., LIU, Y.X., WANG, H.M., HOU, P.L., HE, H.B. and DING, N.Z., 2016. New genetic mechanism, origin and population dynamic of bovine ephemeral fever virus. Veterinary Microbiology, vol. 182, pp. 50-56. http://dx.doi.org/10.1016/j. vetmic.2015.10.029. PMid:26711028.

HOU, P.L., WANG, H.M., ZHAO, G.M., HE, C.Q. and HE, H.B., 2017. Rapid detection of infectious bovine Rhinotracheitis virus using recombinase polymerase amplification assays. BMC Veterinary Research, vol. 13, no. 1, pp. 386. http://dx.doi. org/10.1186/s12917-017-1284-0. PMid:29237466.

HOU, P.L., ZHAO, G.M., HE, C.Q., WANG, H.M. and HE, H.B., 2018. Biopanning of polypeptides binding to bovine ephemeral fever virus $\mathrm{G}(1)$ protein from phage display peptide library. BMC Veterinary Research, vol. 14, no. 1, pp. 3. http://dx.doi. org/10.1186/s12917-017-1315-x. PMid:29301517.

HRISTOVA, M., HABIBOVIC, A., VEITH, C., JANSSENHEININGER, Y.M., DIXON, A.E., GEISZT, M. and VAN DER VLIET, A., 2016. Airway epithelial dual oxidase 1 mediates allergen-induced IL-33 secretion and activation of type 2 immune responses. The Journal of Allergy and Clinical Immunology, vol. 137, no. 5, pp. 1545-1556. http://dx.doi.org/10.1016/j. jaci.2015.10.003. PMid:26597162.

JOO, J.H., RYU, J.H., KIM, C.H., KIM, H.J., SUH, M.S., KIM, J.O., CHUNG, S.Y., LEE, S.N., KIM, H.M., BAE, Y.S. and YOON, J.H., 2012. Dual oxidase 2 is essential for the toll-like receptor 5-mediated inflammatory response in airway mucosa. Antioxidants \& Redox Signalling, vol. 16, no. 1, pp. 57-70. http:// dx.doi.org/10.1089/ars.2011.3898. PMid:21714724.

KIM, H.J., KIM, C.H., KIM, M.J., RYU, J.H., SEONG, S.Y., KIM, S., LIM, S.J., HOLTZMAN, M.J. and YOON, J.H., 2015. The induction of pattern-recognition receptor expression against influenza A virus through Duox2-derived reactive oxygen species in nasal mucosa. American Journal of Respiratory Cell and Molecular Biology, vol. 53, no. 4, pp. 525-535. http://dx.doi. org/10.1165/rcmb.2014-0334OC. PMid:25751630. 
KLEBANOFF, S.J., 2005. Myeloperoxidase: friend and foe. Journal of Leukocyte Biology, vol. 77, no. 5, pp. 598-625. http:// dx.doi.org/10.1189/jlb.1204697. PMid:15689384.

KOFF, J.L., SHAO, M.X., UEKI, I.F. and NADEL, J.A., 2008. Multiple TLRs activate EGFR via a signaling cascade to produce innate immune responses in airway epithelium. American Journal of Physiology. Lung Cellular and Molecular Physiology, vol. 294, no. 6, pp. L1068-L1075. http://dx.doi.org/10.1152/ ajplung.00025.2008. PMid:18375743.

KUMAR, A., VLASOVA, A.N., DEBLAIS, L., HUANG, H.C., WIJERATNE, A., KANDASAMY, S., FISCHER, D.D., LANGEL, S.N., PAIM, F.C., ALHAMO, M.A., SHAO, L., SAIF, L.J. and RAJASHEKARA, G., 2018. Impact of nutrition and rotavirus infection on the infant gut microbiota in a humanized pig model. BMC Gastroenterology, vol. 18, no. 1, pp. 93. http:// dx.doi.org/10.1186/s12876-018-0810-2. PMid:29929472.

LAMBETH, J.D., KAWAHARA, T. and DIEBOLD, B., 2007. Regulation of Nox and Duox enzymatic activity and expression. Free Radical Biology \& Medicine, vol. 43, no. 3, pp. 319-331. http:// dx.doi.org/10.1016/j.freeradbiomed.2007.03.028. PMid:17602947.

LAURINDO, F.R., ARAUJO, T.L. and ABRAHAO, T.B., 2014. Nox NADPH oxidases and the endoplasmic reticulum. Antioxidants \& Redox Signalling, vol. 20, no. 17, pp. 2755-2775. http://dx.doi. org/10.1089/ars.2013.5605. PMid:24386930.

LEE, K.A., CHO, K.C., KIM, B., JANG, I.H., NAM, K., KWON, Y.E., KIM, M., HYEON, D.Y., HWANG, D., SEOL, J.H. and LEE, W.J., 2018. Inflammation-modulated metabolic reprogramming is required for DUOX-dependent gut immunity in Drosophila. Cell Host \& Microbe, vol. 23, no. 3, pp. 338-352. http://dx.doi.org/10.1016/j.chom.2018.01.011. PMid:29503179.

LEE, K.A., KIM, B., BHIN, J., KIM, D.H., YOU, H., KIM, E.K., KIM, S.H., RYU, J.H., HWANG, D. and LEE, W.J., 2015a. Bacterial uracil modulates Drosophila DUOX-dependent gut immunity via Hedgehog-induced signaling endosomes. Cell Host \& Microbe, vol. 17, no. 2, pp. 191-204. http://dx.doi.org/10.1016/j. chom.2014.12.012. PMid:25639794.

LEE, K.A., KIM, B., YOU, H. and LEE, W.J., 2015b. Uracilinduced signaling pathways for DUOX-dependent gut immunity. Fly, vol. 9, no. 3, pp. 115-120. http://dx.doi.org/10.1080/193369 34.2015.1126011. PMid:26655037.

LETO, T.L. and GEISZT, M., 2006. Role of Nox family NADPH oxidases in host defense. Antioxidants \& Redox Signalling, vol. 8, no. 9-10, pp. 1549-1561. http://dx.doi.org/10.1089/ars.2006.8.1549. PMid:16987010.

LETO, T.L., MORAND, S., HURT, D. and UEYAMA, T., 2009. Targeting and regulation of reactive oxygen species generation by Nox family NADPH oxidases. Antioxidants \& Redox Signalling, vol. 11, no. 10, pp. 2607-2619. http://dx.doi. org/10.1089/ars.2009.2637. PMid:19438290.

LI, H., LI, T., GUO, Y., LI, Y., ZHANG, Y., TENG, N., ZHANG, F. and YANG, G., 2018. Molecular characterization and expression patterns of a non-mammalian toll-like receptor gene (TLR21) in larvae ontogeny of common carp (Cyprinus carpio L.) and upon immune stimulation. BMC Veterinary Research, vol. 14, no. 1, pp. 153. http://dx.doi.org/10.1186/s12917-018-1474-4. PMid:29724212.

LI, H., ZHANG, F.M., GUO, H.Y., ZHU, Y.Y., YUAN, J.D., YANG, G.W. and AN, L.G., 2013. Molecular characterization of hepcidin gene in common carp (Cyprinus carpio L.) and its expression pattern responding to bacterial challenge. Fish \&
Shellfish Immunology, vol. 35, no. 3, pp. 1030-1038. http://dx.doi. org/10.1016/j.fsi.2013.07.001. PMid:23851290.

LI, K., PANG, C.H., DING, F., SUI, N., FENG, Z.T. and WANG, B.S., 2012. Overexpression of Suaeda salsa stroma ascorbate peroxidase in Arabidopsis chloroplasts enhances salt tolerance of plants. South African Journal of Botany, vol. 78, pp. 235-245. http://dx.doi.org/10.1016/j.sajb.2011.09.006.

LI, T., LI, H., PENG, S., ZHANG, F., AN, L. and YANG, G., 2017. Molecular characterization and expression pattern of $X$ box-binding protein-1 (XBP1) in common carp (Cyprinus carpio L.): indications for a role of XBP1 in antibacterial and antiviral immunity. Fish \& Shellfish Immunology, vol. 67, pp. 667-674. http://dx.doi.org/10.1016/j.fsi.2017.06.055. PMid:28663129.

LIANG, J.W., TIAN, F.L., LAN, Z.R., HUANG, B. and ZHUANG, W.Z., 2010. Selection characterization on overlapping reading frame of multiple-protein-encoding P gene in Newcastle disease virus. Veterinary Microbiology, vol. 144, no. 3-4, pp. 257-263. http://dx.doi.org/10.1016/j.vetmic.2009.12.029. PMid:20079581.

LINDERHOLM, A.L., ONITSUKA, J., XU, C., CHIU, M., LEE, W.M. and HARPER, R.W., 2010. All-trans retinoic acid mediates DUOX2 expression and function in respiratory tract epithelium. American Journal of Physiology: Lung Cellular and Molecular Physiology, vol. 299, no. 2, pp. L215-L221. http:// dx.doi.org/10.1152/ajplung.00015.2010. PMid:20511343.

LOUZADA, R.A., CORRE, R., AMEZIANE-EL-HASSANI, R., HECHT, F., CAZARIN, J., BUFFET, C., CARVALHO, D.P. and DUPUY, C., 2018. Conformation of the N-terminal ectodomain elicits different effects on DUOX function: a potential impact on congenital hypothyroidism caused by a $\mathrm{H}_{2} \mathrm{O}_{2}$ production defect. Thyroid, vol. 28, no. 8, pp. 1052-1062. http://dx.doi.org/10.1089/ thy.2017.0596. PMid:29845893.

MORENO, J.C., BIKKER, H., KEMPERS, M.J., VAN TROTSENBURG, A.S., BAAS, F., DE VIJLDER, J.J., VULSMA, T. and RIS-STALPERS, C., 2002. Inactivating mutations in the gene for thyroid oxidase 2 (THOX2) and congenital hypothyroidism. The New England Journal of Medicine, vol. 347, no. 2, pp. 95102. http://dx.doi.org/10.1056/NEJMoa012752. PMid:12110737.

MOSKWA, P., LORENTZEN, D., EXCOFFON, K.J., ZABNER, J., MCCRAY JUNIOR, P.B., NAUSEEF, W.M., DUPUY, C. and BANFI, B., 2007. A novel host defense system of airways is defective in cystic fibrosis. American Journal of Respiratory and Critical Care Medicine, vol. 175, no. 2, pp. 174-183. http:// dx.doi.org/10.1164/rccm.200607-1029OC. PMid:17082494.

ORAM, J.D. and REITER, B., 1966. The inhibition of Streptococci by lactoperoxidase, thiocyanate and hydrogen peroxide. The oxidation of thiocyanate and the nature of the inhibitory compound. The Biochemical Journal, vol. 100, no. 2, pp. 382-388. PMid:5338806.

PANG, C.H., LI, K. and WANG, B.S., 2011. Overexpression of SsCHLAPXs confers protection against oxidative stress induced by high light in transgenic Arabidopsis thaliana. Physiologia Plantarum, vol. 143, no. 4, pp. 355-366. http://dx.doi.org/10.1111/ j.1399-3054.2011.01515.x. PMid:21895668.

RADA, B., LEKSTROM, K., DAMIAN, S., DUPUY, C. and LETO, T.L., 2008. The Pseudomonas toxin pyocyanin inhibits the dual oxidase-based antimicrobial system as it imposes oxidative stress on airway epithelial cells. Journal of Immunology, vol. 181, no. 7, pp. 4883-4893. http://dx.doi.org/10.4049/jimmunol.181.7.4883. PMid:18802092

RADA, B. and LETO, T.L., 2008. Oxidative innate immune defenses by Nox/Duox family NADPH oxidases. Contributions 
to Microbiology, vol. 15, pp. 164-187. http://dx.doi. org/10.1159/000136357. PMid:18511861.

REHMAN, Z.U., CHE, L., REN, S., LIAO, Y., QIU, X., YU, S., SUN, Y., TAN, L., SONG, C., LIU, W., DING, Z., MUNIR, M., NAIR, V., MENG, C. and DING, C., 2018. Supplementation of vitamin $\mathrm{E}$ protects chickens from newcastle disease virus-mediated exacerbation of intestinal oxidative stress and tissue damage. Cellular Physiology and Biochemistry, vol. 47, no. 4, pp. 16551666. http://dx.doi.org/10.1159/000490984. PMid:29949793.

RIGUTTO, S., HOSTE, C., GRASBERGER, H., MILENKOVIC, M., COMMUNI, D., DUMONT, J.E., CORVILAIN, B., MIOT, F. and DE DEKEN, X., 2009. Activation of dual oxidases Duox 1 and Duox2: differential regulation mediated by camp-dependent protein kinase and protein kinase $\mathrm{C}$-dependent phosphorylation. The Journal of Biological Chemistry, vol. 284, no. 11, pp. 67256734. http://dx.doi.org/10.1074/jbc.M806893200. PMid:19144650.

ROMBOUT, J., YANG, G.W. and KIRON, V., 2014. Adaptive immune responses at mucosal surfaces of teleost fish. Fish \& Shellfish Immunology, vol. 40, no. 2, pp. 634-643. http://dx.doi. org/10.1016/j.fsi.2014.08.020. PMid:25150451.

SARR, D., TOTH, E., GINGERICH, A. and RADA, B., 2018. Antimicrobial actions of dual oxidases and lactoperoxidase. Journal of Microbiology, vol. 56, no. 6, pp. 373-386. http://dx.doi. org/10.1007/s12275-018-7545-1. PMid:29858825.

SAVAGE, D.C., 1977. Microbial ecology of the gastrointestinal tract. Annual Review of Microbiology, vol. 31, no. 1, pp. 107133. http://dx.doi.org/10.1146/annurev.mi.31.100177.000543. PMid:334036.

SEGAL, A.W., 2005. How neutrophils kill microbes. Annual Review of Immunology, vol. 23, no. 1, pp. 197-223. http://dx.doi. org/10.1146/annurev.immunol.23.021704.115653. PMid:15771570.

SHAN, S., LIU, D., LIU, R., ZHU, Y., LI, T., ZHANG, F., AN, L., YANG, G. and LI, H., 2018. Non-mammalian Toll-like receptor 18 (Tlr18) recognizes bacterial pathogens in common carp (Cyprinus carpio L.): indications for a role of participation in the NF-kappaB signaling pathway. Fish \& Shellfish Immunology, vol. 72, pp. 187-198. http://dx.doi.org/10.1016/j.fsi.2017.09.081. PMid:29111394.

SHAN, S.J., LIU, D.Z., WANG, L., ZHU, Y.Y., ZHANG, F.M., LI, T., AN, L.G. and YANG, G.W., 2015. Identification and expression analysis of irak1 gene in common carp Cyprinus carpio L.: indications for a role of antibacterial and antiviral immunity. Journal of Fish Biology, vol. 87, no. 2, pp. 241-255. http://dx.doi.org/10.1111/jfb.12714. PMid:26099328.

SOMMER, F. and BACKHED, F., 2015. The gut microbiota engages different signaling pathways to induce Duox 2 expression in the ileum and colon epithelium. Mucosal Immunology, vol. 8, no. 2, pp. 372-379. http://dx.doi.org/10.1038/mi.2014.74. PMid:25160818.

STRENGERT, M., JENNINGS, R., DAVANTURE, S., HAYES, P., GABRIEL, G. and KNAUS, U.G., 2014. Mucosal reactive oxygen species are required for antiviral response: role of Duox in influenza a virus infection. Antioxidants \& Redox Signalling, vol. 20, no. 17, pp. 2695-2709. http://dx.doi.org/10.1089/ ars.2013.5353. PMid:24128054.

SUGIURA, H. and ICHINOSE, M., 2008. Oxidative and nitrative stress in bronchial asthma. Antioxidants \& Redox Signalling, vol. 10, no. 4, pp. 785-798. http://dx.doi.org/10.1089/ars.2007.1937. PMid:18177234.
SUZUKI, S., OGAWA, M., OHTA, S., NUNOMURA, S., NANRI, Y., SHIRAISHI, H., MITAMURA, Y., YOSHIHARA, T., LEE, J.J. and IZUHARA, K., 2016. Induction of airway allergic inflammation by hypothiocyanite via epithelial cells. The Journal of Biological Chemistry, vol. 291, no. 53, pp. 27219-27227. http:// dx.doi.org/10.1074/jbc.M116.746909. PMid:27864363.

TANNOCK, G.W., 2005. New perceptions of the gut microbiota: implications for future research. Gastroenterology Clinics of North America, vol. 34, no. 3, pp. 361-382, vii. http://dx.doi. org/10.1016/j.gtc.2005.05.006. PMid:16084302.

VAN DER VLIET, A., DANYAL, K. and HEPPNER, D.E., 2018. Dual oxidase: a novel therapeutic target in allergic disease. British Journal of Pharmacology, vol. 175, no. 9, pp. 1401-1418. http://dx.doi.org/10.1111/bph.14158. PMid:29405261.

WAN, W.Y., HOLLINS, F., HASTE, L., WOODMAN, L., HIRST, R.A., BOLTON, S., GOMEZ, E., SUTCLIFFE, A., DESAI, D., CHACHI, L., MISTRY, V., SZYNDRALEWIEZ, C., WARDLAW, A., SAUNDERS, R., O'CALLAGHAN, C., ANDREW, P.W. and BRIGHTLING, C.E., 2016. NADPH oxidase-4 overexpression is associated with epithelial ciliary dysfunction in neutrophilic asthma. Chest, vol. 149, no. 6, pp. 1445-1459. http://dx.doi.org/10.1016/j.chest.2016.01.024. PMid:26836936.

WEBER, G., RABBIOSI, S., ZAMPRONI, I. and FUGAZZOLA, L., 2013. Genetic defects of hydrogen peroxide generation in the thyroid gland. Journal of Endocrinological Investigation, vol. 36, no. 4, pp. 261-266. PMid:23404134.

WESTFALL, S., LOMIS, N., KAHOULI, I., DIA, S.Y., SINGH, S.P. and PRAKASH, S., 2017. Microbiome, probiotics and neurodegenerative diseases: deciphering the gut brain axis. Cellular and Molecular Life Sciences, vol. 74, no. 20, pp. 3769-3787. http://dx.doi.org/10.1007/s00018-017-2550-9. PMid:28643167.

XIA, L., YANG, Y., WANG, J., JING, Y. and YANG, Q., 2018. Impact of TGEV infection on the pig small intestine. Virology Journal, vol. 15, no. 1, pp. 102. http://dx.doi.org/10.1186/s12985018-1012-9. PMid:29914507.

XIONG, Z., ZHANG, X., ZHANG, S., LEI, L., MA, W., LI, D., WANG, W., ZHAO, Q. and XING, B., 2018. Bacterial toxicity of exfoliated black phosphorus nanosheets. Ecotoxicology and Environmental Safety, vol. 161, pp. 507-514. http://dx.doi. org/10.1016/j.ecoenv.2018.06.008. PMid:29913419.

YANG, G.W., GUO, H.Y., LI, H., SHAN, S.J., ZHANG, X.Q., ROMBOUT, J. and AN, L.G., 2014. Molecular characterization of LEAP-2 cDNA in common carp (Cyprinus carpio L.) and the differential expression upon a Vibrio anguillarum stimulus; indications for a significant immune role in skin. Fish \& Shellfish Immunology, vol. 37, no. 1, pp. 22-29. http://dx.doi.org/10.1016/j. fsi.2014.01.004. PMid:24418455.

YANG, H.T., YANG, M.C., SUN, J.J., SHI, X.Z., ZHAO, X.F. and WANG, J.X., 2016. Dual oxidases participate in the regulation of intestinal microbiotic homeostasis in the kuruma shrimp Marsupenaeus japonicus. Developmental and Comparative Immunology, vol. 59, pp. 153-163. http://dx.doi.org/10.1016/j. dci.2016.01.024. PMid:26845611.

YANG, H.T., ZOU, S.S., ZHAI, L.J., WANG, Y., ZHANG, F.M., AN, L.G. and YANG, G.W., 2017. Pathogen invasion changes the intestinal microbiota composition and induces innate immune responses in the zebrafish intestine. Fish \& Shellfish Immunology, vol. 71, pp. 35-42. http://dx.doi.org/10.1016/j.fsi.2017.09.075. PMid:28964859. 
ZHANG, F.M., LIU, D.Z., WANG, L., LI, T., CHANG, Q., AN, L.G. and YANG, G.W., 2015. Characterization of IgM-binding protein: A pIgR-like molecule expressed by intestinal epithelial cells in the common carp (Cyprinus carpio L.). Veterinary Immunology and Immunopathology, vol. 167, no. 1-2, pp. 30-35. http://dx.doi.org/10.1016/j.vetimm.2015.06.015. PMid:26166176.

ZHANG, Q., XU, Y., CHANG, R., TONG, D. and XU, X., 2018. Transmissible gastroenteritis virus $\mathrm{N}$ protein causes endoplasmic reticulum stress, up-regulates interleukin- 8 expression and its subcellular localization in the porcine intestinal epithelial cell. Research in Veterinary Science, vol. 119, pp. 109-115. http:// dx.doi.org/10.1016/j.rvsc.2018.06.008. PMid:29909129.

ZHENG, S., SHI, J., WU, X., PENG, Z., XIN, C., ZHANG, L., LIU, Y., GAO, M., XU, S., HAN, H., YU, J., SUN, W., CONG, X., LI, J. and WANG, J., 2018. Presence of Torque teno sus virus
1 and 2 in porcine circovirus 3-positive pigs. Transboundary and Emerging Diseases, vol. 65, no. 2, pp. 327-330. http://dx.doi. org/10.1111/tbed.12792. PMid:29285888.

ZHU, Y.Y., QI, C.C., SHAN, S.J., ZHANG, F.M., LI, H., AN, L.G. and YANG, G.W., 2016a. Characterization of common carp (Cyprinus carpio L.) interferon regulatory factor 5 (IRF5) and its expression in response to viral and bacterial challenges. BMC Veterinary Research, vol. 12, no. 1, pp. 127. http://dx.doi. org/10.1186/s12917-016-0750-4. PMid:27350041.

ZHU, Y.Y., XING, W.X., SHAN, S.J., ZHANG, S.Q., LI, Y.Q., LI, T., AN, L. and YANG, G.W., 2016b. Characterization and immune response expression of the Rig-I-like receptor mda5 in common carp Cyprinus carpio. Journal of Fish Biology, vol. 88, no. 6, pp. 2188-2202. http://dx.doi.org/10.1111/jfb.12981. PMid:27108774. 